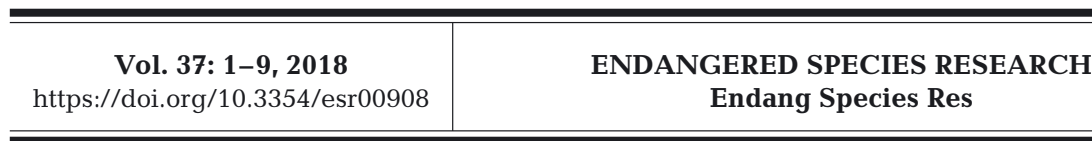

Contribution to the Special 'Marine pollution and endangered species'

\title{
Anthropogenic impacts on green turtles Chelonia mydas in New Zealand
}

\author{
Daniel A. Godoy, Karen A. Stockin \\ Coastal-Marine Research Group, Institute of Natural and Mathematical Sciences, Massey University, Albany, Auckland 0745, \\ New Zealand
}

\begin{abstract}
Conservation strategies to sustain endangered green turtle Chelonia mydas populations must categorise and mitigate a range of anthropogenic threats. This study provides first insights into some of the adverse effects of anthropogenic activities on green turtles at a foraging area in New Zealand. Gross necropsies were conducted on 35 immature and sub-adult green turtles that were stranded in northern New Zealand between 2007 and 2013. Results revealed 54\% ( $n=19)$ of individuals exhibited human-related trauma, and $63 \%$ of these $(n=12)$ had ingested synthetic marine debris. The predominant plastic items ingested were soft plastics (e.g. single-use food packaging, plastic bags), and white, clear or translucent items. No correlation was observed between curved carapace length and the volume or number of synthetic debris items ingested. Propeller strike injuries were identified in $26 \%(n=5)$ of turtles exhibiting human-related effects, while $10 \%(n=2)$ had evidence of incidental capture in recreational fishing activities. Importantly, within New Zealand waters, anthropogenic effects predominantly associated with plastic ingestion are impacting the green turtle aggregation, and may be an important contributory factor to the stranding of immature and sub-adult green turtles in this region. Consequently, the threats identified in this study should be considered when developing population-specific conservation strategies.
\end{abstract}

KEY WORDS: Marine debris ingestion · Single-use plastics $\cdot$ Propeller strike $\cdot$ Incidental capture Fisheries bycatch $\cdot$ Species conservation

\section{INTRODUCTION}

In recent history, human activities have led to a substantial decline in marine biodiversity worldwide (Lewison et al. 2004, Crowder \& Norse 2005, Pereira et al. 2012). These activities include overexploitation and harvesting, bycatch, habitat loss and degradation, pollution, and climate change (Derraik 2002, Newson et al. 2009, Block et al. 2011, Burrows et al. 2011, Gilman 2011). In addition, of increasing concern is the significant and wide-ranging environmental impact of synthetic marine debris, especially plastic pollution (Gregory 2009, Law et al. 2010, Carson 2013). Knowledge of the impact of anthropogenic threats on threatened marine species across temporal

*Corresponding author: d.a.godoy@massey.ac.nz and spatial scales is therefore a critical component of any conservation management plan (Wallace et al. 2011, Koch et al. 2013).

Marine turtles are widely distributed throughout tropical and temperate regions, (Pritchard 1997). These highly migratory species exhibit complex life history patterns that encompass coastal nesting areas, neritic foraging grounds, oceanic habitats, and long-distance migratory pathways (Balazs 1976, Hirth 1997, Lohmann \& Lohmann 1998, Bolten 2003, Luschi et al. 2003, Boyle \& Limpus 2008). Accordingly, marine turtles are exposed to numerous anthropogenic effects across their distributional range and life cycle (Eckert 1995). Thus, although historically abundant, 6 of 7 species have experienced significant declines glob-

(C) The authors 2018. Open Access under Creative Commons by Attribution Licence. Use, distribution and reproduction are unrestricted. Authors and original publication must be credited. 
ally and are now considered Threatened or more under the Red List of the International Union for Conservation of Nature (Seminoff 2004, Abreu-Grobois \& Plotkin 2008, Mortimer \& Donnelly 2008, Wallace et al. 2013a, Casale \& Tucker 2017). Given the complex life history, wide ranging distribution, and significant anthropogenic threats marine turtles are exposed to throughout their lives, conservation managers need an understanding of the types and extent of anthropogenic mortality to formulate appropriate populationspecific mitigation (Seminoff et al. 2002, Wallace et al. 2011, Wallace et al. 2013b).

Marine turtles occupying coastal foraging habitats are at risk of adverse anthropogenic effects including fisheries bycatch, vessel collision, and entanglement in and ingestion of synthetic marine debris (Denkinger et al. 2013, Wallace et al. 2013b, Lewison et al. 2014, Schuyler et al. 2014, Nelms et al. 2016). Marine turtles ingest synthetic marine debris inadvertently if mixed or attached to natural diet items, or if mistaken for natural prey or forage (Carr 1987, Hoarau et al. 2014, Casale et al. 2016). Ingested synthetic debris can accumulate and obstruct, harm, or cause inflammation of the digestive tract, leading to reduced digestive ability, reduced fitness, and even possible mortality (Bjorndal et al. 1994, Casale et al. 2016, Nelms et al. 2016, Schuyler et al. 2016). Other lesser-known consequences of synthetic debris ingestion are dietary dilution (McCauley \& Bjorndal 1999) and the sublethal effects of desorbed or leached organic contaminants from plastics (Moore 2008, Teuten et al. 2009, Engler 2012, Nelms et al. 2016). Schuyler et al. (2012) reported that neritic foraging marine turtles selectively consumed soft clear and white plastics, which resembled their natural prey, such as jellyfish (Carr 1987, Bugoni et al. 2001, Campani et al. 2013). In this regard, Plotkin \& Amos (1990) suggested that small turtles (particularly pelagic stage juveniles) were more likely to ingest plastics, while older neritic phase sub-adults and adults exhibited a size-correlated decrease in plastic consumption. Conversely, Tomás et al. (2002) concluded that the volume of plastic ingested correlated with an increase in curved carapace length (CCL) in loggerhead turtles Caretta caretta in the Mediterranean Sea.

Entanglement in synthetic marine debris (including discarded or lost fishing gear) and bycatch in fisheries activities poses a major threat to marine turtles worldwide (Laist 1997, Lewison et al. 2004, Jensen et al. 2013, Wallace et al. 2013b, Wilcox et al. 2013, Clarke et al. 2014). Incidental capture of marine turtles in pelagic longline, trawl, and coastal gillnet fisheries has also been widely reported (Crowder et al. 1995, McCracken 2000, Robins et al. 2002, Tomás et al. 2008, Donoso \& Dutton 2010, Wallace et al. 2013b). In addition, for many airbreathing vertebrates (e.g. marine mammals and turtles), vessel-related injuries such as propeller strike and blunt force trauma caused by vessel collision may also represent a major cause of injury and mortality (Stockin et al. 2009, Work et al. 2010). For example, in populated coastal communities, such as southeast Florida, up to $60 \%$ of stranded loggerhead turtles exhibit propeller strike injuries (Work et al. 2010).

Monitoring free-ranging marine turtles for anthropogenic impacts at coastal foraging grounds is logistically challenging and therefore often overlooked (Seminoff et al. 2003, Chaloupka et al. 2008, Nelms et al. 2016). However, examinations of stranded turtles from coastal foraging grounds can be used to elucidate key threats to a foraging aggregation (Chaloupka et al. 2008, Cole et al. 2011, Koch et al. 2013). For instance, Casale et al. (2016) suggested that stranded turtles are a good representative of neritic coastal foragers, and thus can reveal important information on the threats and risks to resident populations (Chaloupka et al. 2008). In turn, information derived from such studies can highlight specific population-level impacts and inform future mitigation and conservation strategies (Crowder et al. 1995, Wallace et al. 2011, Casale et al. 2016, Nelms et al. 2016).

In New Zealand, recent research has identified a temperate neritic foraging aggregation of immature green turtles (Godoy et al. 2016, Godoy 2017). The aggregation comprises a mixed-stock foraging ground with links to several genetically distinct management units that span the Pacific Ocean region (Godoy 2017). Although bycatch data suggest green turtles are at risk of incidental capture in commercial fisheries waters around New Zealand (Godoy 2016), other potential threats have not been investigated. Here, we assessed the frequency of anthropogenic effects on green turtles in New Zealand by undertaking post mortem examinations of stranded carcasses. Stranded turtles were assessed to (1) investigate the ingestion of synthetic marine debris and ascertain whether there was a correlation between size (CCL) and number or volume items ingested, (2) determine the type and colour of synthetic debris ingested, (3) identify evidence of entanglement, vessel collision, and bycatch, and (4) describe any other significant contributing factors to green turtle mortality. 


\section{MATERIALS AND METHODS}

Between 2007 and 2013, a total of 48 stranded green turtles were reported in New Zealand (Godoy et al. 2016). Of these, 35 were recovered and assessed for anthropogenic impacts using standard necropsy techniques (Wolke \& George 1981, Flint et al. 2009b). Stranding date, location, and standard CCL $( \pm 0.1 \mathrm{~cm}$ SD) measurements were recorded (Limpus et al. 1994, Bolten 1999). Sex and maturity status were determined by visual or histological examination of the gonads and associated ducts following Rainey (1981) and Limpus \& Reed (1985). Gross lesions, abnormalities, and other potentially relevant indicators were recorded, measured, and photographed.

To investigate whether synthetic debris had been ingested and where it had accumulated, the entire gastrointestinal track was removed and divided into anterior (oesophagus and stomach) and posterior (small and large intestine) sections. The gut was examined for areas of impaction, haemorrhaging, or lesions caused by ingested synthetic debris (as per Flint et al. 2009b). The location of any impaction or related observation within the gastrointestinal tract was recorded and photographed. The contents were then collected and rinsed through a $0.5 \mathrm{~mm}$ fine mesh sieve. Any recovered synthetic debris was washed and dried at room temperature for processing, while all diet items or natural debris (e.g. wood, pumice, feathers) were separated for diet component analysis (Godoy 2017). For each turtle sampled, synthetic debris items were identified and categorised according to type as described in Schuyler et al. (2012): hard plastic, soft plastic, synthetic rope or twine, nonsynthetic rope, fishing items, balloons, other rubber, foam, other (e.g. tar or oil, metal, glass, cloth); and according to colour: white, clear or translucent, red, orange, yellow, green, blue, brown, black, other. The total number of each type and colour of synthetic debris within each turtle was recorded, weighed $( \pm 0.01 \mathrm{~g})$, and volume measured using the volume displacement method with ethanol in a graduated cylinder $( \pm 0.1 \mathrm{ml})$ (Schuyler et al. 2012, Santos et al. 2015a). The total frequency of occurrence (FO) of each type and colour was subsequently quantified (Schuyler et al. 2012). The relative percent abundance of each type and colour of ingested synthetic debris was also calculated for each turtle and expressed as the mean percentage $(\% \mathrm{~A} \pm \mathrm{SE})$ for the entire sample (Schuyler et al. 2012). To investigate the relationship between CCL and the number of synthetic debris items ingested per turtle, a generalised linear model (GLM) was fitted to the data
(McCullagh \& Nelder 1989). A linear regression analysis was performed to determine the relationship between CCL and the ingested volume of synthetic debris items. Volumes were log transformed for regression analysis and alpha was set at 0.05. Analyses were performed using $\mathrm{R}$ software ( $\mathrm{R}$ Development Core Team 2014).

During gross necropsy, turtles were examined for evidence of entanglement in synthetic marine debris, fishing interaction, or vessel strike injuries. Categories were defined as (1) entanglement: turtles presented with evidence of interaction with either discarded fishing gear or other type of synthetic marine debris (i.e. linear rope marks, external lesions, and indentations); (2) fishing interaction: turtles presented with evidence of interaction with active fishing-related gear (e.g. set nets, crayfish pots) or hooks were observed embedded externally (e.g. mouth cavity or flipper) or internally (e.g. swallowed hook and line); (3) vessel or propeller strike: identified as catastrophic blunt trauma (e.g. fractures, haemorrhaging), as multiple evenly spaced parallel lacerations (propeller), or single linear laceration (skeg) (Norem 2005, Flint et al. 2009b, Work et al. 2010, Martinez \& Stockin 2013). A catastrophic injury was defined as any wound that fractured or penetrated the carapace or body, compromising the coelomic cavity, thus presumably causing immediate or delayed mortality via infection (Work et al. 2010).

For each turtle examined, the likely cause or significant contributing factor to mortality was determined based on the most significant and severe finding. For example, where a catastrophic vessel collision injury was identified, and no other external or internal gross pathology observed, vessel strike was considered the most likely cause of mortality. Given the small sample size overall, seasonal, sex, and size class effects could not be statistically tested, therefore only a descriptive summary for each factor is presented.

\section{RESULTS}

All turtles were found stranded (alive or dead) on the coastline of the North Island between ca. $38^{\circ}$ and $34^{\circ} \mathrm{S}$. Stranded turtles were recorded in slightly higher abundance during austral spring $(\mathrm{n}=15) \mathrm{com}-$ pared with summer $(n=6)$, autumn $(n=10)$, and winter $(n=4)$. Turtles ranged in size from 37.3 to $94.6 \mathrm{~cm}$ CCL $(\bar{x}=51.9 \mathrm{~cm}, \mathrm{SD}=12.3, \mathrm{n}=35)$. All turtles were immature juveniles to large sub-adults of both sexes (19 female, 12 male, 4 undetermined). Of the 35 car- 
casses assessed for anthropogenic trauma, $54 \%(\mathrm{n}=19)$ exhibited evidence of human impacts. Twelve individuals (34\%) had ingested synthetic debris.

All but one turtle (ID: 064) contained natural digesta in their gastrointestinal tract. The one exception was also devoid of synthetic debris. In total, 791 pieces of synthetic debris were ingested by 12 turtles, with a mean of $65.9 \pm 37.0$ (SE) pieces per turtle, although ingestion rate was highly variable between individuals (range $=1-432$ ). Similarly, ingested volumes also varied greatly between individuals (range $=0.1-45 \mathrm{ml}, \widetilde{x}=$ $8.6 \mathrm{ml}, \mathrm{SE}=4.6)$. The GLM revealed no correlation between CCL and the number of pieces ingested $\left(\chi^{2}{ }_{10}=1.74, p=0.187\right)$. Similarly, linear regression analysis revealed no correlation between CCL and the volume of synthetic debris ingested $\left(F_{1,10}=\right.$ 1.03, $\mathrm{p}=0.334$ ).

Soft plastic was the most frequent type of plastic consumed $(\mathrm{FO}=91.7 \%)$ and in the largest relative quantity $(\% \mathrm{~A}=56.7 \pm 9.8$; Table 1, Fig. 1). In addition, white (FO = $66.7, \% \mathrm{~A}=24.5 \pm 8.9$ ) and clear or translucent categories $(\mathrm{FO}=83.3, \% \mathrm{~A}=49.6 \pm$ 10.3) were most frequently consumed and in the highest relative quantities (Table 2, Fig. 1). Synthetic debris types identified
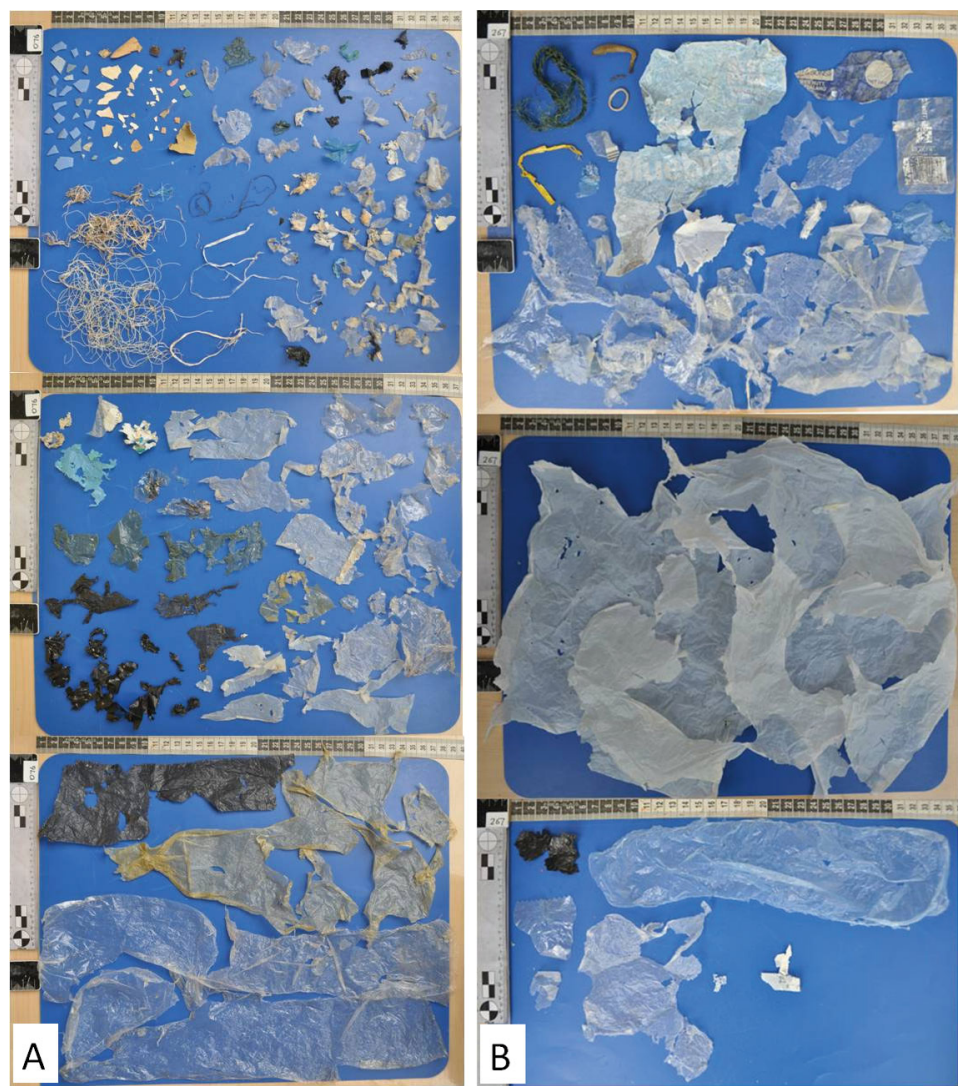

Fig. 1. Examples of synthetic debris ingested by 2 stranded turtles in New Zealand. (A) Turtle A (ID: 076, $43.7 \mathrm{~cm}$ CCL, $7.7 \mathrm{~kg}$ ) and (B) turtle B (ID: 267, 66.4 cm CCL, $28.3 \mathrm{~kg}$ ) exemplifying the prevalence of soft, white and clear or translucent plastics ingested included single-use plastics such as food packaging, balloons, and bags, while fishing line and synthetic 'soft bait' lures were also recorded (Fig. 1, Fig. S1 in the Supplement at www.int-res.com/ articles/suppl/n037p001_supp.pdf). Of the 12 turtles with ingested synthetic debris, 9 contained synthetic debris only in the posterior tract (small and large intestines), while 3 contained synthetic debris in the anterior (stomach) and posterior tract. Four turtles

Table 1. Frequency of occurrence (FO, \%) and relative percentage abundance $(\% \mathrm{~A} \pm \mathrm{SE})$ of synthetic marine debris types observed in the gastrointestinal tract of stranded immature and sub-adult green turtles in New Zealand $(\mathrm{n}=12)$

\begin{tabular}{|lccc|}
\hline Synthetic debris colour & $\mathrm{n}$ & $\mathrm{FO}$ & $\% \mathrm{~A} \pm \mathrm{SE}$ \\
\hline Soft plastic & 11 & 91.7 & $56.7 \pm 9.8$ \\
Plastic rope or twine & 8 & 66.7 & $21.3 \pm 6.4$ \\
Hard plastic & 5 & 41.7 & $10.2 \pm 4.8$ \\
Fishing items & 1 & 8.3 & $8.3 \pm 8.3$ \\
Other rubber & 3 & 25.0 & $2.9 \pm 2.8$ \\
Balloons & 2 & 16.7 & $0.6 \pm 0.4$ \\
Total & & & 100 \\
\hline
\end{tabular}

contained significant amounts of ingested synthetic debris leading to severe impaction of the gastrointestinal tract, with perforation of the intestinal wall recorded in 1 individual (ID: 076). In addition, 1 turtle had ingested fishing line measuring $122.5 \mathrm{~cm}$ that

Table 2. Frequency of occurrence (FO, \%) and relative percentage abundance $(\% \mathrm{~A} \pm \mathrm{SE})$ of synthetic marine debris colours recorded in the gastrointestinal tract of stranded immature and sub-adult green turtles in New Zealand $(n=12)$

\begin{tabular}{|lccc|}
\hline Synthetic debris colour & $\mathrm{n}$ & $\mathrm{FO}$ & $\% \mathrm{~A} \pm \mathrm{SE}$ \\
\hline Clear or translucent & 10 & 83.3 & $49.6 \pm 10.3$ \\
White & 8 & 66.7 & $24.5 \pm 8.9$ \\
Blue & 6 & 50.0 & $7.8 \pm 4.1$ \\
Black & 5 & 41.7 & $1.6 \pm 0.8$ \\
Green & 4 & 33.3 & $3.3 \pm 1.7$ \\
Yellow & 4 & 33.3 & $4.9 \pm 4.1$ \\
Orange & 2 & 16.7 & $0.2 \pm 0.1$ \\
Red & 1 & 8.3 & $2.8 \pm 2.8$ \\
Brown & 3 & 25.0 & $1.5 \pm 1.1$ \\
Other & 3 & 25.0 & $3.7 \pm 2.8$ \\
Total & & & 100 \\
\hline
\end{tabular}


had become lodged in the small intestine, causing severe plication and granulomatous inflammation of the surrounding tissue.

Of the 35 turtles assessed for vessel-related injuries, $5(14 \%)$ exhibited clear evidence of catastrophic propeller strike injuries (e.g. Fig. 2). A further 2 turtles $(6 \%)$ had been categorised as incidentally caught given that recreational hooks were embedded in the oesophagus anteriorly between the tongue and the glottis (Fig. S2 in the Supplement). No turtles exhibited injuries or marks consistent with entanglement either in active or discarded fishing gear, or other synthetic debris.

In the absence of forensic examination, the cause of death could not be conclusively determined, although significant contributing factors were evident in 11 cases. Four turtles exhibited significant gut impaction or intestinal plication; 5 were presented with catastrophic propeller strike injuries; and 2 exhibited evidence of incidental capture in recreational fishing activities.

\section{DISCUSSION}

Gross necropsies were conducted on stranded green turtles found on New Zealand's northern coastline between 2007 and 2013 to identify and describe the anthropogenic impacts that may threaten green turtles in New Zealand waters. Overall, $54 \%(n=19)$ of stranded turtles exhibited anthropogenic impacts, suggesting human activities may have a substantial influence on the stranding rate of green turtles in the New Zealand aggregation. Observed impacts include the ingestion of synthetic marine debris (of terrestrial and marine origin), vessel strike injuries, and incidental capture in recreational fishing activities. The size range of turtles observed in this study was markedly similar to those seen in Godoy et al. (2016), and thus we consider the turtles sampled here as an accurate reflection of the broader population structure (Fig. S3 in the Supplement).

\section{Synthetic debris ingestion}

The extent of synthetic debris ingestion identified here was similar to the amounts reported for benthic foraging green turtles in Australia (Schuyler et al. 2012) and fell mid-range within the levels reviewed from studies worldwide by Nelms et al. (2016). Similarly, studies at other foraging grounds, including the Mediterranean (Casale et al. 2016), southern Brazil (Bugoni et al. 2001), and eastern Australia (Schuyler et al. 2012), showed that soft plastics and white or clear or translucent items are the most prevalent synthetic debris types ingested. It is unclear whether the items consumed by green turtles in New Zealand proportionally reflect the quantity of synthetic marine debris discharged (and therefore available for incidental consumption) or whether they are selectivity consumed i.e. mistaken for natural forage or prey.
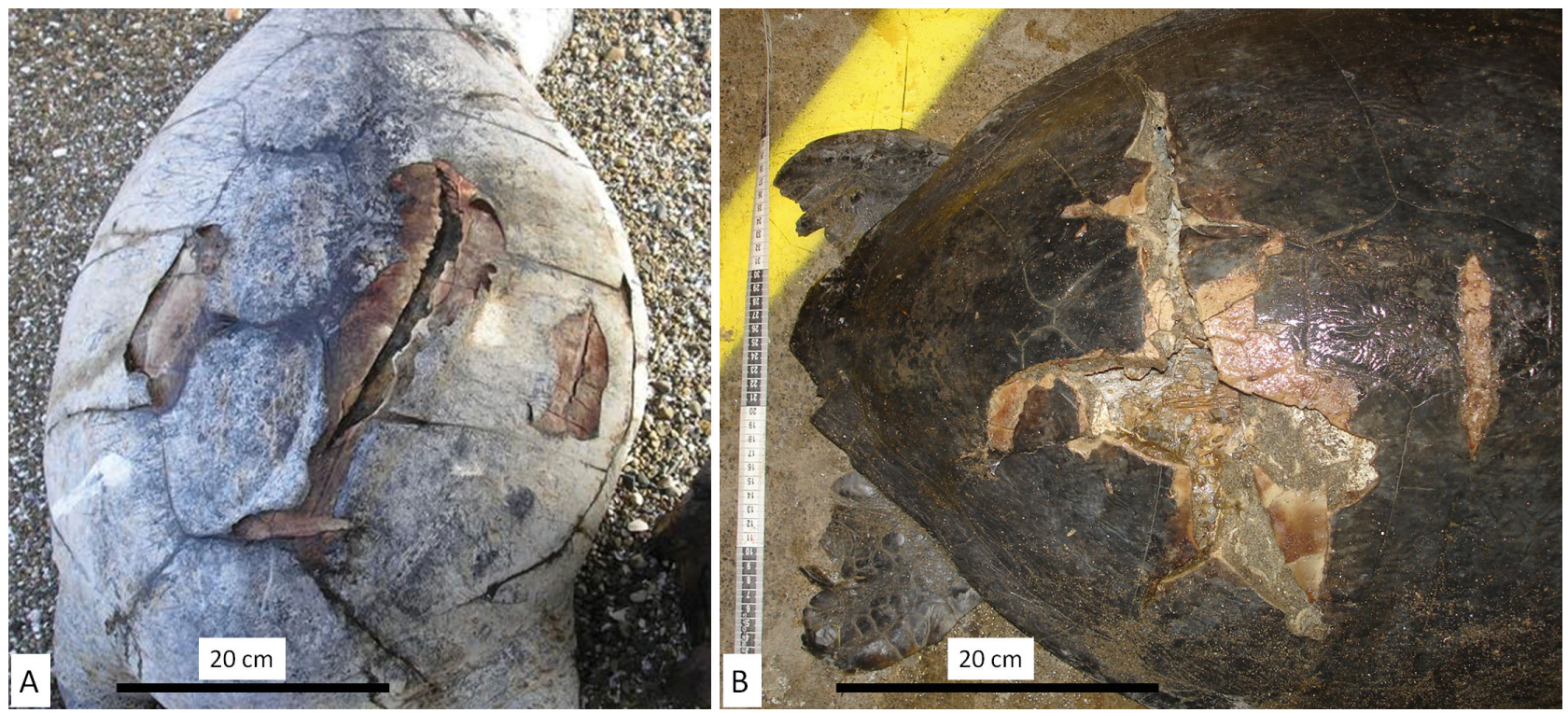

Fig. 2. Examples of 2 stranded green turtles exhibiting catastrophic propeller strike injuries. Note the evenly spaced parallel lacerations causing severe fracture and penetration of the carapace in both (A) turtle A (ID: 094, 77.3 cm CCL) and (B) turtle B (ID: 267, $76.2 \mathrm{~cm}$ CCL) 
However, Schuyler et al. (2012) reported that when compared with marine litter abundance (as a measure of availability) in eastern Australia, neritic turtles selectively consumed white and clear soft plastics over hard and coloured items. In addition, of particular note was a prevalence of single-use plastics (e.g. food packaging and plastic bags) recorded in the gastrointestinal tracts of several turtles. The pervasiveness of single-use plastics observed in this study and others (e.g. Santos et al. 2015b) is concerning given that this category of plastic has been shown to be the fastest-growing component of waste today (Moore 2008).

The adverse impact of discarded land-based plastic waste on marine species is often further intensified where large urban centres are located near coastal zones, as opposed to non-urban or rural regions, because they often generate and discharge relatively higher volumes of plastic pollution out to sea (Moore 2008). For marine turtles occupying neritic foraging grounds near these highly urbanised areas, the impact of discharged waste may therefore have a considerable negative effect (Nelms et al. 2016). Auckland, New Zealand's largest urban and industrialized centre, is located adjacent to the Hauraki Gulf, where compared with other national centres, relatively high discharged concentrations of marine litter have been recorded (Gregory 1991, Backhurst \& Cole 2000, Bayley \& Goodyear 2004, Young \& Adams 2010). Accordingly, because this region also overlaps a core neritic habitat for green turtles in New Zealand (Godoy et al. 2016), we consider individuals occupying this region may be at higher risk of marine debris ingestion than turtles from other parts of New Zealand. In addition, given the lack of correlation between the size of turtles examined and the volume or number of pieces ingested, the data suggest that the risk of synthetic debris ingestion is uniform across the aggregation, which is in accordance with other studies of similar-sized neritic foraging green turtles (e.g. Bugoni et al. 2001, Schuyler et al. 2012).

\section{Vessel collision and fisheries interactions}

Given that post-pelagic green turtles often recruit to occupy shallow embayments, estuaries, and harbours (Hirth 1997, Limpus et al. 2005, Koch et al. 2007, Bresette et al. 2010), they are also at risk of vessel collision injuries and bycatch, particularly in areas adjacent to densely populated coastal regions (Limpus et al. 1994). Our results support this, since $86 \%$ of all turtles exhibiting vessel collision injuries (propeller strike) or captured in recreational fisheries, were recovered near Auckland (Waitemata) or Whangarei harbours. These highly urbanised regions have high levels of recreational and commercial vessel traffic and have been shown to also have higher incidences of fatal vessel collisions for marine mammals (Martinez \& Stockin 2013, Dwyer et al. 2014). Although there was evidence of incidental capture in recreational fisheries, commercial fisheries interactions were not identified. Despite this, recent research suggests that green turtles occupying this northeastern region of New Zealand are at risk from inshore commercial fisheries activities (Godoy 2016).

Entanglement was not identified as a cause of injury or mortality in this study; however, mortality caused by entanglement (mainly via asphyxia and drowning) in fishing nets is difficult to identify due to an absence of visible lesions and is, therefore, often underestimated (Bugoni et al. 2001). Despite a lack of evidence of entanglement of green turtles in the present study entanglement of other marine species in fishing gear in New Zealand has been observed, including leatherback turtles Dermochelys coriacea (D. A. Godoy et al. unpubl.), marine mammals (Slooten \& Dawson 1995, Boren et al. 2006, Stockin et al. 2009), and seabirds (Abraham \& Thompson 2011, Bell 2014). Furthermore, entanglement in active or discarded fishing gear is a significant issue for marine turtle mortality in other regions (e.g. northern Australia and the Mediterranean) and therefore its potential risk in New Zealand cannot be overlooked (Nelms et al. 2016, Schuyler et al. 2016).

\section{Causes of mortality}

Conclusively diagnosing the cause of mortality in stranded marine animals is difficult and requires comprehensive histopathological post-mortem examinations of fresh carcasses (Chaloupka et al. 2008, Flint et al. 2009a, Stockin et al. 2009). It should be noted, therefore, that comprehensive histopathological or toxicological samples were not collected during gross necropsies, and therefore other effects (e.g. disease, anthropogenic related chemical toxicity) were not examined here. While this was not logistically feasible in the present study, in several cases reported herein, gross necropsies still revealed incidences of ingested synthetic debris, incidental capture, and catastrophic propeller strike trauma severe enough to conclude that these factors were the leading probable cause of mortality. For example, pro- 
peller strike was deemed the leading probable cause of mortality in at least 2 cases given that (1) antemortem body condition was good (absence of muscle or adipose atrophy), (2) there was an absence of any obvious gross pathology (abnormalities, lesions, epibiont or parasite load), and (3) significant hemorrhaging and trauma was evident around the wound sites, indicating the turtles were alive at the time of impact. In addition, fresh digesta in the stomach and crop suggested they had been foraging immediately prior to death. Therefore, evidence suggests that in both cases, these turtles died because of the injuries sustained.

In relation to mortality due to ingested synthetic marine debris, 4 turtles exhibited severe gut impaction of the intestinal tract due to the accumulation of synthetic debris. This resulted in severe inflammation, perforation, or plication of the intestinal tract, leading to the conclusion (based on gross analysis) that these turtles most probably died because of ingesting synthetic marine debris. Such an inference is plausible given that Santos et al. (2015b) quantified that amounts as low as $0.5 \mathrm{~g}$ are sufficient to block the digestive tract and cause death in juvenile turtles. In their study, synthetic debris-induced mortality was estimated at $39.4 \%$ compared with $42 \%$ reported here.

\section{CONCLUSION}

This study provides the first description of the predominant sources of anthropogenic impacts affecting green turtle populations within northern New Zealand. The range and magnitude of impact observed herein reflects the threats reported globally, with ingested synthetic debris and propeller strike being the most important precursors to stranding and mortality. However, the present work suggests that the risk of such impacts will be considerably higher for turtles inhabiting neritic habitats adjacent to densely populated urban centres of northeastern New Zealand. Importantly, the focal aggregation comprises a mixed-stock foraging ground with links to genetically distinct populations from across the Pacific Ocean (Godoy 2017). Thus, this study identifies several adverse human impacts that may impact those distant source populations of this wideranging endangered species. In turn, this underscores the need to consider all potential threats across a population's entire distributional range and congruent jurisdictions to appropriately scale conservation strategies.
Acknowledgements. We are grateful to the field staff of the Department of Conservation, the Northland Community and Kelly Tarlton's Sea Life Aquarium for their logistical support during the course of this work. Thanks to B. Outhwaite and C. Lea (C-MRG, Massey University) and C. Blomfield for their kind assistance during necropsies; and Brett Gartrell School of Veterinary Science, Massey University) for support with histological screening. A special thanks to D. Feary and 3 anonymous reviewers who provided valuable comments that improved the quality of the manuscript. This research was authorised by the Department of Conservation Research Permits AK-30931-FAU, NO-2611-RES, AK26280-RES and AK-26092-RES; and Massey University Animal Ethics approved protocols 10/05, 11/62 and 14/73. D.A.G. was supported by a Doctoral fees scholarship awarded by the Institute of Natural and Mathematical Sciences, Massey University, Auckland.

\section{LITERATURE CITED}

Abraham ER, Thompson FN (2011) Summary of the capture of seabirds, marine mammals, and turtles in New Zealand commercial fisheries, 1998-99 to 2008-09. New Zealand aquatic environment and biodiversity report. Ministry of fisheries, Wellington

Abreu-Grobois A, Plotkin PT (2008) Lepidochelys olivacea. The IUCN Red List of Threatened Species 2008. IUCN SSC Marine Turtle Specialist Group, Gland, p 6-8

Backhurst M, Cole R (2000) Biological impacts of boating at Kawau Island, north-eastern New Zealand. J Environ Manage 60:239-251

Balazs GH (1976) Green turtle migrations in the Hawaiian archipelago. Biol Conserv 9:125-140

Bayley A, Goodyear R (2004) New Zealand: an urban /rural profile. Statistics New Zealand, Wellington

Bell E (2014) Identification of seabirds captured in New Zealand fisheries: 1 July 2013-30 June 2014. Report prepared by Wildlife Management International for the New Zealand Department of Conservation, Wellington

Bjorndal KA, Bolten AB, Lagueux CJ (1994) Ingestion of marine debris by juvenile sea turtles in coastal Florida habitats. Mar Pollut Bull 28:154-158

* Block BA, Jonsen ID, Jorgensen SJ, Winship AJ and others (2011) Tracking apex marine predator movements in a dynamic ocean. Nature 475:86-90

Bolten AB (1999) Techniques for measuring sea turtles. In: Eckert KL, Bjorndal KA, Abreu-Grobois FA, Donnelley $M$ (eds) Research and management techniques for the conservation of sea turtles. IUCN/SSC Marine Turtle Specialist Group, Washington, DC, p 110-114

Bolten AB (2003) Variation in sea turtle life history patterns: neritic vs. oceanic developmental stages. In: Lutz PL, Musick J, Wyneken J (eds) The biology of sea turtles, Vol II. CRC Press, Boca Raton, FL, p 243-257

* Boren LJ, Morrissey M, Muller CG, Gemmell NJ (2006) Entanglement of New Zealand fur seals in man-made debris at Kaikoura, New Zealand. Mar Pollut Bull 52: 442-446

Boyle MC, Limpus CJ (2008) The stomach contents of posthatchling green and loggerhead sea turtles in the southwest Pacific: an insight into habitat association. Mar Biol 155:233-241

Bresette MJ, Witherington BE, Herren RM, Bagley DA and others (2010) Size-class partitioning and herding in a foraging group of green turtles Chelonia mydas. Endang Species Res 9:105-116 
Bugoni L, Krause L, Petry MV (2001) Marine debris and human impacts on sea turtles in southern Brazil. Mar Pollut Bull 42:1330-1334

* Burrows MT, Schoeman DS, Buckley LB, Moore P and others (2011) The pace of shifting climate in marine and terrestrial ecosystems. Science 334:652-655

Campani T, Baini M, Giannetti M, Cancelli F and others (2013) Presence of plastic debris in loggerhead turtle stranded along the Tuscany coasts of the Pelagos Sanctuary for Mediterranean Marine Mammals (Italy). Mar Pollut Bull 74:225-230

Carr A (1987) Impact of nondegradable marine debris on the ecology and survival outlook of sea turtles. Mar Pollut Bull 18:352-356

* Carson HS (2013) The incidence of plastic ingestion by fishes: from the prey's perspective. Mar Pollut Bull 74:170-174

Casale P, Tucker AD (2017) Caretta caretta (amended version of 2015 assessment). e. T3897A119333622. The IUCN Red List of Threatened Species 2017: www.iucnredlist. org/details/full/3897/0 (accessed 12 Aug 2018)

Casale P, Freggi D, Paduano V, Oliverio M (2016) Biases and best approaches for assessing debris ingestion in sea turtles, with a case study in the Mediterranean. Mar Pollut Bull 110:238-249

Chaloupka MY, Work TM, Balazs GH, Murakawa SKK, Morris R (2008) Cause-specific temporal and spatial trends in green sea turtle strandings in the Hawaiian Archipelago (1982-2003). Mar Biol 154:887-898

Clarke S, Sato M, Small C, Sullivan B, Inoue Y, Ochi D (2014) Bycatch in longline fisheries for tuna and tunalike species. A global review of status and mitigation measures. FAO Fisheries and Aquaculture Technical Paper No. 588. FAO, Rome

* Cole M, Lindeque P, Halsband C, Galloway TS (2011) Microplastics as contaminants in the marine environment: a review. Mar Pollut Bull 62:2588-2597

Crowder LB, Norse EA (2005) Threats to marine biological diversity. In: Soulé ME (ed) Marine conservation biology: the science of maintaining the sea's biodiversity. Island Press, Washington, DC, p 105-108

Crowder LB, Hopkins-Murphy SR, Royle JA (1995) Effects of turtle excluder devices (TEDs) on loggerhead sea turtle strandings with implications for conservation. Copeia 1995:773-779

* Denkinger J, Parra M, Muñoz JP, Carrasco C and others (2013) Are boat strikes a threat to sea turtles in the Galapagos Marine Reserve? Ocean Coast Manage 80:29-35

Derraik JGB (2002) The pollution of the marine environment by plastic debris: a review. Mar Pollut Bull 44:842-852

Donoso M, Dutton PH (2010) Sea turtle bycatch in the Chilean pelagic longline fishery in the southeastern Pacific: opportunities for conservation. Biol Conserv 143: 2672-2684

* Dwyer SL, Kozmian-Ledward L, Stockin KA (2014) Shortterm survival of severe propeller strike injuries and observations on wound progression in a bottlenose dolphin. NZ J Mar Freshw Res 48:294-302

Eckert KL (1995) Anthropogenic threats to sea turtles. In: Bjorndal KA (ed) Biology and conservation of sea turtles. Smithsonian Institution Press, Washington DC, p 611-612

Engler RE (2012) The complex interaction between marine debris and toxic chemicals in the ocean. Environ Sci Technol 46:12302-12315

Flint M, Patterson-Kane JC, Limpus CJ, Work TM, Blair D, Mills PC (2009a) Postmortem diagnostic investigation of disease in free-ranging marine turtle populations: a review of common pathologic findings and protocols. J Vet Diagn Invest 21:733-759

Flint M, Patterson-kane J, Mills P, Limpus CJ (2009b) A veterinarian's guide for sea turtle post mortem examination and histological investigation. University of Queensland, Brisbane

Gilman EL (2011) Bycatch governance and best practice mitigation technology in global tuna fisheries. Mar Policy 35:590-609

Godoy DA (2016) Marine reptiles-review of interactions and populations. Report prepared by Karearea Consultants for the New Zealand Department of Conservation, Wellington

Godoy DA (2017) The ecology and conservation of green turtles (Chelonia mydas) in New Zealand. PhD thesis, Massey University, Auckland

Godoy DA, Smith ANH, Limpus CJ, Stockin KA (2016) The spatio-temporal distribution and population structure of green turtles (Chelonia mydas) in New Zealand. NZ J Mar Freshw Res 50:549-565

* Gregory MR (1991) The hazards of persistent marine pollution: drift plastics and conservation islands. J R Soc NZ 21:83-100

*Gregory MR (2009) Environmental implications of plastic debris in marine settings-entanglement, ingestion, smothering, hangers-on, hitch-hiking and alien invasions. Philos Trans R Soc Lond B Biol Sci 364:2013-2025

Hirth HF (1997) Synopsis of biological data on the green turtle Chelonia mydas (Linnaeus 1758). US Fish and Wildlife Service. Biol Reprod 97:1-120

* Hoarau L, Ainley L, Jean C, Ciccione S (2014) Ingestion and defecation of marine debris by loggerhead sea turtles, Caretta caretta, from by-catches in the South-West Indian Ocean. Mar Pollut Bull 84:90-96

Jensen MP, Limpus CJ, Whiting SD, Guinea M and others (2013) Defining olive ridley turtle Lepidochelys olivacea management units in Australia and assessing the potential impact of mortality in ghost nets. Endang Species Res 21:241-253

*KKoch V, Brooks LB, Nichols WJ (2007) Population ecology of the green/black turtle (Chelonia mydas) in Bahía Magdalena, Mexico. Mar Biol 153:35-46

Koch V, Peckham H, Mancini A, Eguchi T (2013) Estimating at-sea mortality of marine turtles from stranding frequencies and drifter experiments. PLOS ONE 8:e56776

Laist DW (1997) Impacts of marine debris: entanglement of marine life in marine debris including a comprehensive list of species with entanglement and ingestion records. In: Coe JM, Rogers DB (eds) Marine debris: sources, impacts, and solutions. Springer, New York, NY, p 99-139

K Law KL, Morét-Ferguson S, Maximenko NA, Proskurowski G, Peacock EE, Hafner J, Reddy CM (2010) Plastic accumulation in the North Atlantic subtropical gyre. Science 329:1185-1188

Lewison RL, Crowder LB, Read AJ, Freeman SA (2004) Understanding impacts of fisheries bycatch on marine megafauna. Trends Ecol Evol 19:598-604

Lewison RL, Crowder LB, Wallace BP, Moore JE and others (2014) Global patterns of marine mammal, seabird, and sea turtle bycatch reveal taxa-specific and cumulative megafauna hotspots. Proc Natl Acad Sci USA 111: 5271-5276

Limpus CJ, Reed PC (1985) The green turtle, Chelonia mydas, in Queensland: a preliminary description of the population structure in a coral reef feeding ground. In: Grigg G, Shine R, Ehmann H (eds) The biology of Australasian frogs and reptiles. Surrey Beatty \& Sons, Sydney, p 47-52 
Limpus CJ, Couper PJ, Read MA (1994) The green turtle, Chelonia mydas, in Queensland: population structure in a warm temperate feeding area. Mem Queensl Mus 35: 139-154

Limpus CJ, Limpus DJ, Arthur KE, Parmenter CJ (2005) Monitoring green turtle population dynamics in Shoalwater Bay: 2000-2004. Great Barrier Reef Marine Park Authority Research Publication Series, Vol 83. Great Barrier Reef Marine Park Authority, Townsville

Lohmann KJ, Lohmann CMF (1998) Sea turtle navigation and the detection of geomagnetic field features. J Nav 51:10-22

Luschi P, Hays GC, Papi F (2003) A review of long-distance movements by marine turtles, and the possible role of ocean currents. Oikos 103:293-302

Martinez E, Stockin KA (2013) Blunt trauma observed in a common dolphin Delphinus sp. likely caused by a vessel collision in the Hauraki Gulf, New Zealand. Pac Conserv Biol 19:19-27

McCauley SJ, Bjorndal KA (1999) Conservation implications of dietary dilution from debris ingestion: sublethal effects in post hatchling loggerhead sea turtles. Conserv Biol 13: 925-929

McCracken ML (2000) Estimation of sea turtle take and mortality in the Hawaiian longline fisheries. NOAA Admin Rep NMFS-SFSC-H-00-06. SWFSC, NMFS, Honolulu, HI

McCullagh P, Nelder JA (1989) Generalized linear models, 2nd edn. Chapman \& Hall, Boca Raton, FL

Moore CJ (2008) Synthetic polymers in the marine environment: a rapidly increasing, long-term threat. Environ Res 108:131-139

* Mortimer JA, Donnelly M (2008) Eretmochelys imbricata. The IUCN Red List of Threatened Species 2008: e.T8005 A12881238. http://dx.doi.org/10.2305/IUCN.UK.2008. RLTS.T8005A12881238.en (accessed 14 Jun 2016)

Nelms SE, Duncan EM, Broderick AC, Galloway TS and others (2016) Plastic and marine turtles: a review and call for research. ICES J Mar Sci 73:165-181

Newson SE, Mendes S, Crick HQP, Dulvy NK and others (2009) Indicators of the impact of climate change on migratory species. Endang Species Res 7:101-113

Norem AD (2005) Injury assessment of sea turtles utilizing the neritic zone of the southeastern United States. MSc thesis, University of Florida, Gainesville, FL

Pereira HM, Navarro LM, Martins IS (2012) Global biodiversity change: the bad, the good, and the unknown. Annu Rev Environ Resour 37:25-50

Plotkin P, Amos AF (1990) Effects of anthropogenic debris on sea turtles in the Northwestern Gulf of Mexico. In: Shomura RS, Godfrey L (eds) Proc 2nd Int Conf Marine Debris, 2-7 April 1989. NOAA Tech Memo NOAA-TMNMFS-SWFSC-154. NMFS, Honolulu, HI, p 769-743

Pritchard PCH (1997) Evolution, phylogeny, and current status. In: Lutz PL, Musick JA (eds) The biology of sea turtles. CRC Press, Boca Raton, FL, p 432

R Development Core Team (2014) R: a language and environment for statistical computing. R Foundation for Statistical Computing, Vienna. www.r-project.org/

Rainey W (1981) Guide to sea turtle visceral anatomy. NOAA Tech Memo NMFS-SEFSC-82. NMFS, Miami, FL

Robins CM, Goodspeed AM, Poiner IR, Harch BD (2002) Monitoring the catch of turtles in the Northern Prawn Fishery. Fisheries Research and Development Corporation Final Report. Bureau of Rural Sciences, Canberra

Santos RG, Martins AS, Batista MB, Horta PA (2015a) Regional and local factors determining green turtle Chelonia mydas foraging relationships with the environment. Mar Ecol Prog Ser 529:265-277
Santos RG, Andrades R, Boldrini MA, Martins AS (2015b) Debris ingestion by juvenile marine turtles: an underestimated problem. Mar Pollut Bull 93:37-43

* Schuyler Q, Hardesty BD, Wilcox C, Townsend K (2012) To eat or not to eat? Debris selectivity by marine turtles. PLOS ONE 7:e40884

Schuyler Q, Hardesty BD, Wilcox C, Townsend K (2014) Global analysis of anthropogenic debris ingestion by sea turtles. Conserv Biol 28:129-139

Schuyler QA, Wilcox C, Townsend KA, Wedemeyer-Strombel KR, Balazs G, van Sebille E, Hardesty BD (2016) Risk analysis reveals global hotspots for marine debris ingestion by sea turtles. Glob Change Biol 22:567-576

* Seminoff JA (2004) Chelonia mydas. The IUCN Red List of Threatened Species 2004: e.T4615A11037468. http://doi. org/10.2305/IUCN.UK.2004.RLTS.T4615A11037468.en (accessed 14 Jun 2016)

* Seminoff JA, Resendiz A, Nichols WJ (2002) Home range of green turtles Chelonia mydas at a coastal foraging area in the Gulf of California, Mexico. Mar Ecol Prog Ser 242: 253-265

* Seminoff JA, Todd Jones T, Resendiz A, Nichols WJ, Chaloupka MY (2003) Monitoring green turtles (Chelonia mydas) at a coastal foraging area in Baja California, Mexico: multiple indices to describe population status. J Mar Biol Assoc UK 83:1355-1362

Slooten E, Dawson SM (1995) Conservation of marine mammals in New Zealand. Pac Conserv Biol 2:64-76

* Stockin KA, Duignan PJ, Roe WD, Meynier L, Alley M, Fetterman $T$ (2009) Causes of mortality in stranded common dolphin (Delphinus sp.) from New Zealand waters between 1998 and 2008. Pac Conserv Biol 15:217-227

* Teuten EL, Saquing JM, Knappe DRU, Barlaz MA and others (2009) Transport and release of chemicals from plastics to the environment and to wildlife. Philos Trans R Soc Lond B Biol Sci 364:2027-2045

Tomás J, Guitart R, Mateo R, Raga JA (2002) Marine debris ingestion in loggerhead sea turtles, Caretta caretta, from the Western Mediterranean. Mar Pollut Bull 44:211-216

* Tomás J, Gozalbes P, Raga JA, Godley BJ (2008) Bycatch of loggerhead sea turtles: insights from 14 years of stranding data. Endang Species Res 5:161-169

Wallace BP, DiMatteo AD, Bolten AB, Chaloupka MY and others (2011) Global conservation priorities for marine turtles. PLOS ONE 6:e24510

Wallace BP, Tiwari M, Girondot M (2013a) Dermochelys coriacea. The IUCN Red List of Threatened Species 2013: e.T6494A43526147. http://dx.doi.org/10.2305/IUCN. UK.2013-2.RLTS.T6494A43526147.en (accessed 14 Jun 2016)

Wallace BP, Kot CY, DiMatteo AD, Lee T, Crowder LB, Lewison RL (2013b) Impacts of fisheries bycatch on marine turtle populations worldwide: toward conservation and research priorities. Ecosphere 4:40

Wilcox C, Hardesty BD, Sharples R, Griffin DA, Lawson TJ, Gunn R (2013) Ghostnet impacts on globally threatened turtles, a spatial risk analysis for northern Australia. Conserv Lett 6:247-254

Wolke RE, George A (1981) Sea turtle necropsy manual. NOAA Tech Memo NMFS-SEFC-24. NMFS, Panama City, FL

Work PA, Sapp AL, Scott DW, Dodd MG (2010) Influence of small vessel operation and propulsion system on loggerhead sea turtle injuries. J Exp Mar Biol Ecol 393:168-175

Y Young M, Adams NJ (2010) Plastic debris and seabird presence in the Hauraki Gulf, New Zealand. NZ J Mar Freshw Res 44:167-175 